\title{
ZnO Nanoparticles as an Efficient, Heterogeneous, Reusable, and Ecofriendly Catalyst for Four-Component One-Pot Green Synthesis of Pyranopyrazole Derivatives in Water
}

\author{
Harshita Sachdeva and Rekha Saroj \\ Department of Chemistry, Faculty of Engineering and Technology, Mody Institute of Technology and Science, Lakshmangarh, \\ Sikar, Rajasthan 332311, India
}

Correspondence should be addressed to Harshita Sachdeva; drhmsachdevaster@gmail.com

Received 19 August 2013; Accepted 12 September 2013

Academic Editors: E. Le Gall and A. Sacchetti

Copyright (C) 2013 H. Sachdeva and R. Saroj. This is an open access article distributed under the Creative Commons Attribution License, which permits unrestricted use, distribution, and reproduction in any medium, provided the original work is properly cited.

An extremely efficient catalytic protocol for the synthesis of a series of pyranopyrazole derivatives developed in a one-pot fourcomponent approach in the presence of $\mathrm{ZnO}$ nanoparticles as heterogeneous catalyst using water as a green solvent is reported. Greenness of the process is well instituted as water is exploited both as reaction media and medium for synthesis of catalyst. The $\mathrm{ZnO}$ nanoparticles exhibited excellent catalytic activity, and the proposed methodology is capable of providing the desired products in good yield (85-90\%) and short reaction time. After reaction course, $\mathrm{ZnO}$ nanoparticles can be recycled and reused without any apparent loss of activity which makes this process cost effective and hence ecofriendly. All the synthesized compounds have been characterized on the basis of elemental analysis, IR, ${ }^{1} \mathrm{H}$ NMR, and ${ }^{13} \mathrm{C}$ NMR spectral studies.

\section{Introduction}

Multicomponent reactions (MCRs) occupy an interesting position in organic synthesis because of their atom economy, simple procedures, and convergent character [1-3]. Applications of MCRs in drug discovery, material sciences, natural product synthesis, and ligand and biological probe preparations further demonstrate the power of this reaction $[4,5]$.

Catalysis has played a vital role in the success of the industry [6]. The use of transition-metal nanoparticles in catalysis is crucial as they mimic metal surface activation and catalysis at the nanoscale and thereby bring selectivity and efficiency to heterogeneous catalysis [7-14]. Among transition-metal nanoparticles, $\mathrm{ZnO}$ nanoparticles have been of considerable interest because of the role of $\mathrm{ZnO}$ in solar cells, catalysts, antibacterial materials, gas sensors, luminescent materials, and photocatalyst [15]. The recent literature survey reveals that nano- $\mathrm{ZnO}$ as heterogeneous catalyst has received considerable attention because it is inexpensive, nontoxic catalyst and has environmental advantages, that is, minimum execution time, low corrosion, waste minimization, recycling of the catalyst, easy transport, and disposal of the catalyst.
In recent years, in biological field, the potential utility of $\mathrm{ZnO}$ nanoparticle in the treatment of cancer has been reported by many researchers. Owing to numerous advantages associated with this ecofriendly nature, it has been explored as a powerful catalyst for several organic transformations [16-21] such as Mannich reaction, and the Knoevenagel condensation reaction, in the synthesis of coumarins, quinolines, polyhydroquinoline, 2,3disubstituted quinalolin-4(1H)-ones, and benzimidazole.

Pyrazole derivatives constitute an interesting class of heterocycles due to their synthetic versatility and effective biological activities [22-28]. Further, pyrano[2,3-c]pyrazoles constitute one of the privileged heterocyclic scaffolds known to exhibit important biological activities [29-32]. Nowadays, there has been increasing interest in the development of nonhazardous alternatives such as water-mediated syntheses, multicomponent reactions, and reusable heterogeneous catalysts for the sustainable development of chemical enterprise. Although numerous methods to achieve pyranopyrazoles are known [33-44], simple, environmentally benign approaches are still demanded. 


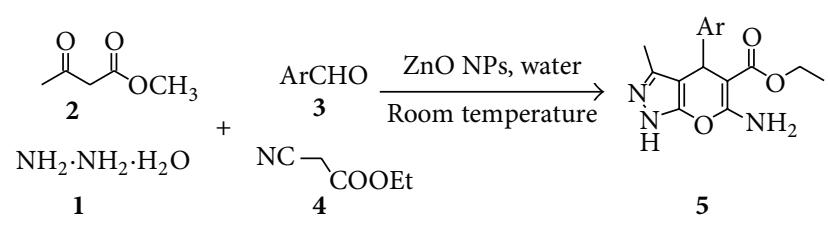

Ar = 3,4-dimethoxyphenyl, 3-methoxyphenyl, 3,4,5-trimethoxyphenyl,

4-Cl phenyl, 4-methoxyphenyl, 3-methyl-2-furyl, 2-thienyl, 3-pyridyl,

2-OH phenyl, 3-OH, 4- $\mathrm{OCH}_{3}$ phenyl.

SCHEME 1

Hence, in continuation of our work to develop ecofriendly techniques for heterocyclic synthesis [45-47], an attempt has been made to synthesize pyranopyrazole derivatives by the reaction of hydrazine hydrate, methyl acetoacetate, substituted aromatic aldehydes, and ethyl cyanoacetate in water using $\mathrm{ZnO}$ nanoparticles as catalyst at room temperature $\left(25^{\circ} \mathrm{C}\right)$ under the framework of green chemistry (Scheme 1).

The process described here offers rapid facile one-pot synthesis of pyranopyrazole derivatives using easily recyclable $\mathrm{ZnO}$ nanoparticles. This process is cost effective and eco-friendly as it is one-pot synthesis with easy work-up and does not require harsh reagents. To the best of our knowledge, there is no report available in the literature describing the use of $\mathrm{ZnO}$ nanoparticles as catalysts for the synthesis of pyranopyrazole carboxyethylester derivatives. The effectiveness of the process was studied by comparing the results obtained with and without catalyst under normal conditions.

\section{Experimental}

2.1. General. Reagents and solvents were obtained from commercial sources and used without further purification. Melting points were determined on a Toshniwal apparatus. The spectral analyses of synthesized compounds have been carried out at SAIF, Punjab University, Chandigarh. Purity of all compounds was checked by TLC using "G" coated glass plates and benzene: ethyl acetate $(8: 2)$ as eluent. IR spectra were recorded in $\mathrm{KBr}$ on a Perkin Elmer Infrared RXI FTIR spectrophotometer, and ${ }^{1} \mathrm{H}$ NMR spectra were recorded on Bruker Avance II 400 NMR spectrometer using DMSO- $\mathrm{d}_{6}$ and $\mathrm{CDCl}_{3}$ as solvent and tetramethylsilane (TMS) as internal reference standard. The obtained products were identified from their spectral $\left({ }^{1} \mathrm{H}\right.$ NMR, ${ }^{13} \mathrm{C}$ NMR, and IR) data. The microwave-assisted reactions were carried out in a Catalysts Systems Scientific Multimode MW oven attached with a magnetic stirrer and reflux condenser, operating at $700 \mathrm{~W}$ generating $2450 \mathrm{MHz}$ frequency.

2.2. General Procedure for the Synthesis of $\mathrm{ZnO}$ Nanoparticles in Water. ZnO nanoparticles were synthesized by two different methods.

2.2.1. Method A. $\mathrm{ZnO}$ nanorods are prepared according to a literature method developed by Pacholski et al. [48] with some modification. Firstly, zinc acetate $\left(\mathrm{Zn}(\mathrm{Ac})_{2}, 2.4 \mathrm{~g}\right)$ and $126 \mathrm{~mL}$ of water were added into a round bottom flask. The solution was heated to $60^{\circ} \mathrm{C}$ with magnetic stirring. Potassium hydroxide $(\mathrm{KOH}, 1.2 \mathrm{~g})$ was dissolved into $70 \mathrm{~mL}$ of water as the stock solution that is dropped into the flask within $10-15 \mathrm{~min}$. At a constant temperature of $60^{\circ} \mathrm{C}$, it takes $2 \mathrm{hrs}$ and $15 \mathrm{~min}$. A small amount of water was found helpful to increase the $\mathrm{ZnO}$ nanocrystal growth rate. To grow the nanorods, the solution is condensed to about $10-15 \mathrm{~mL}$. This was found helpful before further heating to decrease the growth time of the nanorods. Then it is reheated for another $5 \mathrm{hrs}$ before stopping the heating and stirring. The upper fraction of the solution is removed after $30 \mathrm{~min}$. Water $(50 \mathrm{~mL})$ is added to the solution and stirred for $5 \mathrm{~min}$. The upper fraction of the solution is discarded again after $30 \mathrm{~min}$. This process is repeated twice. After being dried under vacuum, $\mathrm{ZnO}$ nanoparticles were obtained (yield: $85 \%$.)

2.2.2. Method B. Zinc acetate and hydrazine hydrate were mixed in a molar ratio of $1: 4$ in water under stirring. Hydrazine readily reacted with zinc acetate to form a slurrylike precipitate of the hybrid complex between them. The stirring of the slurry was continued for $15 \mathrm{~min}$, and then the mixture was subjected to microwave irradiation at $150 \mathrm{~W}$ microwave power for $10 \mathrm{~min}$. The slurry became clear with a white precipitate at the bottom. The precipitate was filtered off, washed with absolute ethanol and distilled water several times and then dried in vacuum at $60^{\circ} \mathrm{C}$ for $4 \mathrm{hrs}$ (yield: $78 \%$.)

\subsection{Synthesis of 3-Methylpyrano[2,3-c]pyrazole Derivatives} (5a-j). A mixture of hydrazine hydrate (1) $(1 \mathrm{mmol})$, methyl acetoacetate (2) (1 mmol), substituted aromatic aldehyde (3) $(1 \mathrm{mmol})$, ethylcyano acetate (4) $(1 \mathrm{mmol})$, and $\mathrm{ZnO}$ nanoparticle $(9 \mathrm{~mol} \%)$ in water $(2 \mathrm{~mL})$ was magnetically stirred at room temperature $\left(25^{\circ} \mathrm{C}\right)$ for $55-60 \mathrm{~min}$. Progress of the reaction was monitored by TLC. After completion of the reaction, the resulting solidified mixture was diluted with ethyl acetate $(5 \mathrm{~mL})$, the catalyst was separated, and the reaction mixture was subjected for solvent-extraction again using ethyl acetate $(3 \times 10 \mathrm{~mL})$. Thus obtained portion of organic layer (ethyl acetate) was concentrated on rotary evaporator under reduced pressure to achieve the desired product. This crude product was purified by recrystallization from ethanol. Results are given in Table 1 . $\mathrm{ZnO}$ nanoparticles thus obtained were washed with methanol and could be reused for the next cycle. The catalyst retained optimum activity till three cycles after which drop in yield was observed (Figure 1).

Synthesis of $\mathbf{5 e}$ by Conventional $\Delta$ Heating. For comparison's sake, compound $\mathbf{5 e}$ was also synthesized by conventional $\Delta$ heating. An equimolar mixture of hydrazine hydrate (1) $(1 \mathrm{mmol})$, methyl acetoacetate $(2)(1 \mathrm{mmol}), 4$-methoxy benzaldehyde (3) (1 mmol), ethylcyano acetate $(4)(1 \mathrm{mmol})$, and $\mathrm{ZnO}$ nanoparticles $(9 \mathrm{~mol} \%)$ in water $(2 \mathrm{~mL})$ was refluxed for $40 \mathrm{~min}$. Progress of the reaction was monitored by TLC using ethyl acetate: benzene $=2: 8$ as eluent. After completion of the reaction, the mixture was subjected to solvent-extraction 
TABLE 1: Nano-ZnO catalyzed synthesis of pyrano[2,3-c]pyrazole derivatives in water at room temperature (5a-j).

\begin{tabular}{|c|c|c|c|c|}
\hline Entry & $\mathrm{Ar}$ & Time (min.) & Yield (\%) & M.P. $\left({ }^{\circ} \mathrm{C}\right)$ \\
\hline $\begin{array}{l}\text { Ethyl-6-amino-1,4-dihydro-4-(3,4-dimethoxyphenyl)-3- } \\
\text { methylpyrano[2,3-c]pyrazole-5-carboxylate } \\
\text { (5a) }\end{array}$ & 3,4-Dimethoxyphenyl & 60 & 90 & 135 \\
\hline $\begin{array}{l}\text { Ethyl-6-amino-1,4-dihydro-4-(3-methoxyphenyl)-3- } \\
\text { methylpyrano[2,3-c]pyrazole-5-carboxylate } \\
\text { (5b) }\end{array}$ & 3-Methoxyphenyl & 55 & 85 & 120 \\
\hline $\begin{array}{l}\text { Ethyl-6-amino-1,4-dihydro-4-(3,4,5-trimethoxyphenyl)-3- } \\
\text { methylpyrano[2,3-c]pyrazole-5-carboxylate } \\
\text { (5c) }\end{array}$ & 3,4,5-Trimethoxyphenyl & 55 & 86 & 160 \\
\hline $\begin{array}{l}\text { Ethyl-6-amino-4-(4-chlorophenyl)-1,4-dihydro-3-methylpyrano[2,3- } \\
\text { c]pyrazole-5-carboxylate } \\
\text { (5d) }\end{array}$ & 4-Chlorophenyl & 60 & 87 & 140 \\
\hline $\begin{array}{l}\text { Ethyl-6-amino-1,4-dihydro-4-(4-methoxyphenyl)-3- } \\
\text { methylpyrano[2,3-c]pyrazole-5-carboxylate } \\
\text { (5e) }\end{array}$ & 4-methoxyphenyl & 55 & 89 & 130 \\
\hline $\begin{array}{l}\text { Ethyl-6-amino-1,4-dihydro-3-methyl-4-(5-methylfuran-2- } \\
\text { yl)pyrano[2,3-c]pyrazole-5-carboxylate } \\
\text { (5f) }\end{array}$ & 3-methyl-2-furyl & 60 & 86 & 142 \\
\hline $\begin{array}{l}\text { Ethyl-6-amino-1,4-dihydro-3-methyl-4-(thiophen-2-yl)pyrano[2,3- } \\
\text { c]pyrazole-5-carboxylate } \\
\mathbf{( 5 g )}\end{array}$ & 2-thienyl & 55 & 87 & 115 \\
\hline $\begin{array}{l}\text { Ethyl-6-amino-1,4-dihydro-3-methyl-4-(pyridin-3-yl)pyrano[2,3- } \\
\text { c]pyrazole-5-carboxylate } \\
\text { (5h) }\end{array}$ & 3-pyridyl & 60 & 85 & 125 \\
\hline $\begin{array}{l}\text { Ethyl-6-amino-1,4-dihydro-4-(2-hydroxyphenyl)-3-methylpyrano[2,3- } \\
\text { c]pyrazole-5-carboxylate } \\
\text { (5i) }\end{array}$ & 2-Hydroxyphenyl & 60 & 87 & 143 \\
\hline $\begin{array}{l}\text { Ethyl-6-amino-1,4-dihydro-4-(3-hydroxy-4-methoxy } \\
\text { phenyl)-3-methylpyrano[2,3-c]pyrazole-5-carboxylate }(5 \mathbf{j})\end{array}$ & 3-hydroxy, 4-methoxyphenyl & 60 & 85 & 145 \\
\hline
\end{tabular}

using ethyl acetate, and obtained portion of organic layer was concentrated on rotary evaporator under reduced pressure to achieve the desired product. This crude product was purified by recrystallization from ethanol. The comparative results obtained by different methods for the synthesis of compound $5 \mathbf{e}$ are given in Table 4.

2.4. Regeneration of Catalyst. To examine the reusability, the catalyst was recovered by filtration from the reaction mixture after dilution with ethyl acetate, washed with methanol, and reused as such for subsequent experiments (up to three cycles) under similar reaction conditions. The observed fact that yields of the product remained comparable in these experiments (Figure 1) established the recyclability and reusability of the catalyst without any significant loss of activity.

\section{Results and Discussion}

An environ-economic synthesis of ethyl-6-amino-1, 4-dihydro-3-methyl-4-substituted pyrano[2,3-c]pyrazole-5-carboxylate derivatives $(\mathbf{5} \mathbf{a}-\mathbf{j})$ is carried out by the reaction of hydrazine hydrate (1), methylacetoacetate (2), substituted

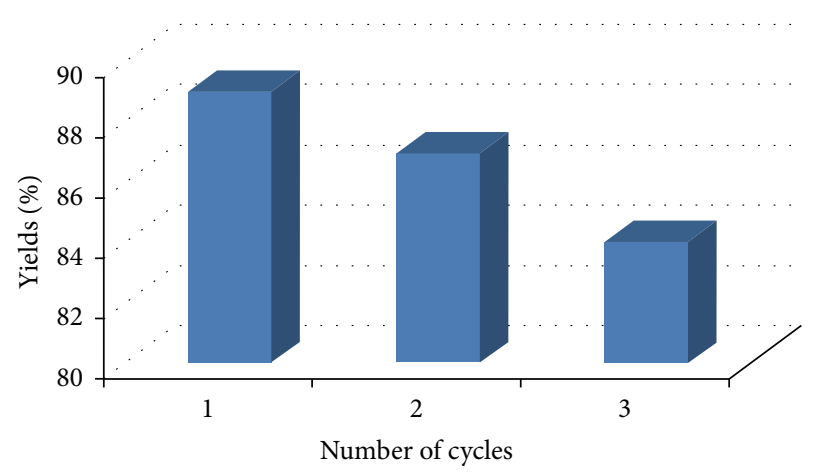

FIGURE 1: Recyclability of $\mathrm{ZnO}$ nanoparticles.

aromatic aldehydes (3), and ethylcyano acetate (4) in the presence of catalytic amount of $\mathrm{ZnO}$ nanoparticle as catalyst under stirring at room temperature $25^{\circ} \mathrm{C}$ in the presence of water (Scheme 1) (Table 1). Reaction of methylacetoacetate, hydrazine hydrate, 4-methoxy benzaldehyde, and ethylcyanoacetate (5e) was chosen as the model substrate to optimize reaction condition including type of catalyst and concentration of catalyst. 
TABLE 2: Screening of catalysts for one-pot condensation of ethyl cyanoacetate, hydrazine hydrate, 4-methoxy benzaldehyde, and methyl acetoacetate.

\begin{tabular}{lcccc}
\hline Entry & Catalyst & \multicolumn{1}{c}{ Catalyst (mol \%) } & Yield (\%) & Time (min.) \\
\hline $\mathbf{5 e}$ & Alum & 3 & 66 & 110 \\
$\mathbf{5 e}$ & ZnO nps & 9 & 89 & 60 \\
$\mathbf{5 e}$ & Mont K10 & 7 & 75 & 80 \\
$\mathbf{5 e}$ & $\mathrm{P}_{2} \mathrm{O}_{5}$ & 5 & 68 & 110 \\
$\mathbf{5 e}$ & Acidic alumina & 7 & 63 & 100 \\
$\mathbf{5 e}$ & Silica & 12 & 69 & 100 \\
$\mathbf{5 e}$ & Mont KSF & 7 & 58 & 90 \\
$\mathbf{5 e}$ & Glacial acetic acid & 12 & 60 & 90 \\
\hline
\end{tabular}

Reaction conditions: hydrazine hydrate (1) $(1 \mathrm{mmol})$, methyl acetoacetate (2) (1 mmol), 4-methoxy benzaldehyde (3) (1 mmol), and ethylcyano acetate (4) $(1 \mathrm{mmol})$ in water $(2 \mathrm{~mL})$.

TABLE 3: Effect of solvent on the reaction of ethyl cyanoacetate, hydrazine hydrate, 4-methoxy benzaldehyde, and methyl acetoacetate under stirring at room temperature.

\begin{tabular}{lccc}
\hline Entry & Solvent & Time $(\mathrm{min})$ & Yield (\%) \\
\hline $\mathbf{1}$ & Ethanol & 90 & 62 \\
$\mathbf{2}$ & Methanol & 80 & 68 \\
$\mathbf{3}$ & Water & 60 & 89 \\
\hline
\end{tabular}

Reaction conditions: hydrazine hydrate (1) $(1 \mathrm{mmol})$, methyl acetoacetate (2) (1 mmol), 4-methoxy benzaldehyde (3) $(1 \mathrm{mmol})$, ethylcyano acetate (4) $(1 \mathrm{mmol})$, and $\mathrm{ZnO}$ nanoparticle $(9 \mathrm{~mol} \%)$.

We have extensively studied the reaction using various catalysts such as alum, Montmorillonite-K10 clay, $\mathrm{P}_{2} \mathrm{O}_{5}$, acidic alumina, silica, Montmorillonite-KSF clay, glacial acetic acid, and $\mathrm{ZnO}$ nanoparticles (Table 2). The results showed that $\mathrm{ZnO}$ nanoparticle provided the highest yield (89\%). The effect of solvents was also examined for the above reaction, and the results indicate that solvents affected the efficiency of the reaction. Yields were poor in ethanol and methanol under stirring at room temperature. However, the best results were obtained in the presence of water (Table 3). In order to confirm the effective involvement of $\mathrm{ZnO}$ nanoparticle during this transformation, we carried out the model reaction without any catalyst. In the absence of $\mathrm{ZnO}$ nanoparticle, the reaction was incomplete even after $8 \mathrm{hrs}$ of stirring at room temperature and $6 \mathrm{hrs}$ of conventional $\Delta$ heating (Table 4 ). Traces of product were observed on TLC.

Encouraged by these results, we have extended this reaction to variously substituted aromatic aldehydes under similar conditions using $\mathrm{ZnO}$ nanoparticle as a catalyst to furnish the respective pyranopyrazole derivatives in excellent yields (85-90\%) without the formation of any side products. Further, we have emphasized the amount of $\mathrm{ZnO}$ nanoparticle to be used in this reaction. We found that the yields were obviously affected by the amount of $\mathrm{ZnO}$ nanoparticles loaded. When 3, 6, 9, and $12 \mathrm{~mol} \%$ of $\mathrm{ZnO}$ nanoparticles was used, the yields were $75 \%, 82.06 \%, 89 \%$, and $89 \%$, respectively. Therefore, $9 \mathrm{~mol} \%$ of $\mathrm{ZnO}$ nano particles were sufficient to push the reaction forward, and, further, increasing the amount of $\mathrm{ZnO}$ nanoparticles did not increase the yields (Table 5).

The above results indicate that $\mathrm{ZnO}$ nanoparticle was essential in the reaction and the best results were obtained when the reaction was carried out with $9 \mathrm{~mol} \%$ of $\mathrm{ZnO}$ nanoparticles at room temperature.

The proposed mechanism for the formation of the product would be as follows. The $\mathrm{ZnO}$ nanoparticle facilitates the Knoevenagel type coupling through Lewis acid sites $\left(\mathrm{Zn}^{+2}\right)$ coordinated to the oxygen of carbonyl groups of methylacetoacetate. On the other hand, $\mathrm{ZnO}$ nanoparticles can activate ethylcyanoacetate so that deprotonation of the $\mathrm{C}-\mathrm{H}$ bond occurs in the presence of Lewis basic sites $\left(\mathrm{O}^{-2}\right)$. As a result, the formation of pyranopyrazole derivatives proceeds by activation of reactants through both Lewis acids and basic sites of $\mathrm{ZnO}$ nanoparticles. The reaction occurs via initial formation of arylidene ethylcyanoacetate by the Knoevenagel condensation between aromatic aldehyde and ethyl cyanoacetate and pyrazolone by the reaction of methyl acetoacetate and hydrazine hydrate. Finally, the Michael addition of pyrazolone to arylidene ethylcyanoacetate followed by cyclization and tautomerization yields pyranopyrazole.

The synthesis of $\mathrm{ZnO}$ nanoparticles was carried out in distilled water for its inherent advantages as it is simple, cost effective, environmentally benign, and easily scaled up for large scale synthesis, and in this method there is no need to use high pressure, high temperature, and toxic chemicals. Additionally, water served as a suitable solvent for the current transformation as well.

Reusability (and hence recyclability) is one of the important properties of this catalyst. The catalyst could be recycled easily, simply by solvent extraction of the product from the reaction mixture using ethyl acetate. The catalyst retained optimum activity till three cycles after which drop in yield was observed (Figure 1). A comparison of efficiency of catalytic activity of $\mathrm{ZnO}$ nanoparticles with other catalysts is presented in Table 2. The results show that this method is superior to other methods in terms of yield and reaction time.

The nanostructure of $\mathrm{ZnO}$ nanoparticle has been studied at room temperature by using X-ray diffraction pattern. Figure 2 shows XRD pattern of $\mathrm{ZnO}$ nanoparticles. The particle size was calculated from X-ray diffraction images of $\mathrm{ZnO}$ powders using Scherrer formula as follows:

$$
D=\frac{K \lambda}{\beta \cos \theta},
$$

where $D$ is the average particle size perpendicular to the reflecting planes, $\lambda$ is the $\mathrm{X}$-ray wavelength, $\beta$ is the full width at half maximum (FWHM), and $\theta$ is the diffraction angle. The average size of $\mathrm{ZnO}$ nanoparticles obtained from the XRD is about $5.1 \mathrm{~nm}$, using the Scherrer formula.

The spectroscopic characterization data of the synthesized compounds are given below.

Ethyl-6-amino-1,4-dihydro-4-(3,4-dimethoxyphenyl)-3-methylpyrano[2,3-c]pyrazole-5-carboxylate (5a). M.P. $135^{\circ} \mathrm{C}$; IR (KBr): 3411, 3355, 3082, 2943, 1729, $1142 \mathrm{~cm}^{-1} ;{ }^{1} \mathrm{H}$ NMR 
TABLE 4: Comparison of catalytic activity of $\mathrm{ZnO}$ nanoparticles in the synthesis of compound $\mathbf{5 e}$ by conventional $(\Delta)$ heating method and stirring at $25^{\circ} \mathrm{C}$.

\begin{tabular}{|c|c|c|c|c|}
\hline Entry & Conditions & Types of catalysts & Reaction time (hrs/min.) & Yield (\%) \\
\hline $\mathrm{OCH}_{3}$ & Stirring $\left(25^{\circ} \mathrm{C}\right)$ & No catalyst & $8 \mathrm{hrs}$ & Traces \\
\hline & Stirring $\left(25^{\circ} \mathrm{C}\right)$ & Nano-ZnO & $60 \mathrm{~min}$ & 89 \\
\hline & $\Delta$ & No catalyst & $6 \mathrm{hrs}$ & Traces \\
\hline & $\Delta$ & Nano-ZnO & $40 \mathrm{~min}$ & 55 \\
\hline
\end{tabular}

TABLE 5: Optimization of the $\mathrm{ZnO}$ nanoparticle catalyzed model reaction for synthesis of $\mathbf{5 e}$.

\begin{tabular}{lcc}
\hline Entry & Catalyst $(\mathrm{mol} \%)$ & Yield $(\%)$ \\
\hline $\mathbf{1}$ & 3 & 75 \\
$\mathbf{2}$ & 6 & 82 \\
$\mathbf{3}$ & 9 & 89 \\
\hline
\end{tabular}

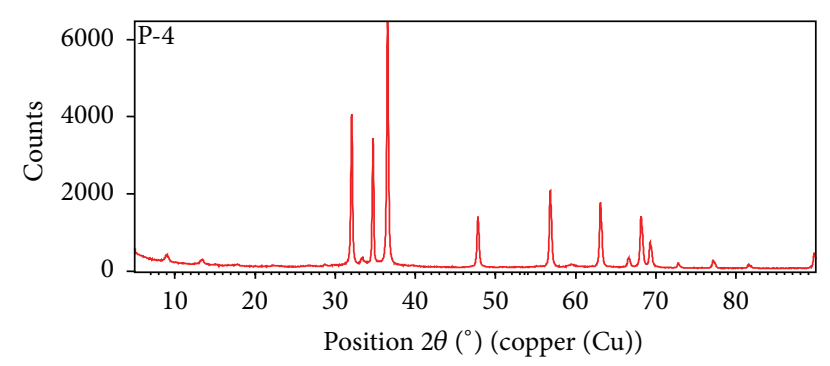

FIgURE 2: XRD Pattern of $\mathrm{ZnO}$ nanoparticles.

$\left(\mathrm{DMSO}_{-} \mathrm{d}_{6}\right): 1.30\left(\mathrm{t}, 3 \mathrm{H}, \mathrm{CH}_{3}\right), 2.79\left(\mathrm{~s}, 3 \mathrm{H}, \mathrm{CH}_{3}\right), 3.73(\mathrm{~s}, 6 \mathrm{H}$, $\left.2 \times \mathrm{OCH}_{3}\right) 4.19\left(\mathrm{q}, 2 \mathrm{H}, \mathrm{CH}_{2}\right), 4.74(\mathrm{~s}, 1 \mathrm{H}, \mathrm{CH}), 6.46-6.54$ (m, 3H, ArH), 7.06 (s, 2H, NH NH $_{2}, 12.08$ (s, 1H, NH) ppm. ${ }^{13} \mathrm{C}$ NMR (400 MHz, DMSO): 10.34, 13.66, 38.84, 55.64, 61.80, $78.74,114.12-132.38,140.06,146.8,160.32,164.28$ ppm. Anal. calcd for $\mathrm{C}_{18} \mathrm{H}_{21} \mathrm{~N}_{3} \mathrm{O}_{5}$ : C, 60.16; $\mathrm{H}, 5.89 ; \mathrm{N}, 11.69$. Found: C, 60.00; H, 5.91; N, 11.67.

Ethyl-6-amino-1,4-dihydro-4-(3-methoxyphenyl)-3-methylpyrano[2,3-c]pyrazole-5-carboxylate (5b). M.P. $120^{\circ} \mathrm{C}$; IR (KBr): 3419, 3351, 3100, 2933, 1719, $1158 \mathrm{~cm}^{-1} ;{ }^{1} \mathrm{H}$ NMR (DMSO-d 6 ): $1.31\left(\mathrm{t}, 3 \mathrm{H}, \mathrm{CH}_{3}\right), 2.78\left(\mathrm{~s}, 3 \mathrm{H}, \mathrm{CH}_{3}\right), 3.72\left(\mathrm{~s}, 3 \mathrm{H}, \mathrm{OCH}_{3}\right)$ $4.20\left(\mathrm{q}, 2 \mathrm{H}, \mathrm{CH}_{2}\right), 4.72(\mathrm{~s}, 1 \mathrm{H}, \mathrm{CH}), 6.48-7.03(\mathrm{~m}, 4 \mathrm{H}$, ArH), 7.07 (s, 2H, $\mathrm{NH}_{2}$ ), 12.09 (s, 1H, NH) ppm. ${ }^{13} \mathrm{C} \mathrm{NMR}$ (400 MHz, DMSO): 10.36, 13.64, 38.82, 55.62, 61.88, 78.78, $111.32-132.32,140.02,159.12,160.38,164.12$ ppm. Anal. calcd for $\mathrm{C}_{17} \mathrm{H}_{19} \mathrm{~N}_{3} \mathrm{O}_{4}$ : C, 62.00; H, 5.81; N, 12.76. Found: C, 62.17; $\mathrm{H}, 5.79 ; \mathrm{N}, 12.74$.

Ethyl-6-amino-1,4-dihydro-4-(3,4,5-trimethoxyphenyl)-3methylpyrano[2,3-c]pyrazole-5-carboxylate (5c). M.P. $160^{\circ} \mathrm{C}$; IR (KBr): 3410, 3359, 3092, 2949, 1722, $1153 \mathrm{~cm}^{-1} ;{ }^{1} \mathrm{H}$ NMR
$\left(\mathrm{DMSO}_{6}\right): 1.30\left(\mathrm{t}, 3 \mathrm{H}, \mathrm{CH}_{3}\right), 2.50\left(\mathrm{~s}, 3 \mathrm{H}, \mathrm{CH}_{3}\right), 3.86(\mathrm{~s}, 9 \mathrm{H}$, $\left.3 \times \mathrm{OCH}_{3}\right) 4.18\left(\mathrm{q}, 2 \mathrm{H}, \mathrm{CH}_{2}\right), 4.70(\mathrm{~s}, 1 \mathrm{H}, \mathrm{CH}), 6.02-6.12$ (m, 2H, ArH), 7.04 (s, 2H, NH $\left.\mathrm{NH}_{2}\right), 12.03$ (s, 1H, NH) ppm. ${ }^{13} \mathrm{C}$ NMR (400 MHz, DMSO): 10.32, 13.62, 38.86, 55.66, 61.82, 78.76, 105.38-132.32, 140.02, 152.12, 160.38, 164.28 ppm. Anal. calcd for $\mathrm{C}_{19} \mathrm{H}_{23} \mathrm{~N}_{3} \mathrm{O}_{6}$ : C, 58.60; H, 5.95; N, 10.79. Found: C, $58.81 ; \mathrm{H}, 5.94 ; \mathrm{N}, 10.80$.

Ethyl-6-amino-4-(4-chlorophenyl)-1,4-dihydro-3-methylpyrano [2,3-c]pyrazole-5-carboxylate (5d). M.P. $140^{\circ} \mathrm{C}$; IR (KBr): 3411, 3355, 3082, 2943, 1729, $848 \mathrm{~cm}^{-1} ;{ }^{1} \mathrm{H}$ NMR (DMSO-d 6 ): $1.27\left(\mathrm{t}, 3 \mathrm{H}, \mathrm{CH}_{3}\right), 2.77\left(\mathrm{~s}, 3 \mathrm{H}, \mathrm{CH}_{3}\right), 4.22\left(\mathrm{q}, 2 \mathrm{H}, \mathrm{CH}_{2}\right)$, 4.71 (s, 1H, CH), 7.02-7.15 (m, 4H, ArH), 7.02 (s, 2H, $\mathrm{NH}_{2}$ ), 12.05 (s, 1H, NH) ppm. ${ }^{13} \mathrm{C}$ NMR (400 MHz, DMSO): 10.32 , 13.68, 38.82, 61.88, 78.76, 128.82-130.56, 116.04-132.32, 131.30, $140.02,160.32,164.22 \mathrm{ppm}$. Anal. calcd for $\mathrm{C}_{16} \mathrm{H}_{16} \mathrm{ClN}_{3} \mathrm{O}_{3}$ : C, 57.58; H, 4.83; N, 12.59. Found: C, 57.76; H, 4.85; N, 12.58 .

Ethyl-6-amino-1,4-dihydro-4-(4-methoxyphenyl)-3-methylpyrano[2,3-c]pyrazole-5-carboxylate (5e). M.P. $130^{\circ} \mathrm{C}$; IR (KBr): 3415, 3350, 3095, 2963, 1739, $1152 \mathrm{~cm}^{-1} ;{ }^{1} \mathrm{H}$ NMR $\left(\mathrm{DMSO}_{-} \mathrm{d}_{6}\right): 1.28\left(\mathrm{t}, 3 \mathrm{H}, \mathrm{CH}_{3}\right), 2.75\left(\mathrm{~s}, 3 \mathrm{H}, \mathrm{CH}_{3}\right), 3.71(\mathrm{~s}$, $\left.3 \mathrm{H}, \mathrm{OCH}_{3}\right) 4.17$ (q, 2H, $\mathrm{CH}_{2}$ ), $4.73(\mathrm{~s}, 1 \mathrm{H}, \mathrm{CH}), 6.65-6.95$ (m, 4H, ArH), 7.03 (s, 2H, NH $\mathrm{N}_{2}$, 12.02 (s, 1H, NH) ppm. ${ }^{13} \mathrm{C}$ NMR (400 MHz, DMSO): 10.34, 13.62, 38.82, 55.68, 61.86, 78.72, 114.22-132.38, 140.04, 156.22, 159.44, 160.36, 164.24 ppm. Anal. calcd for $\mathrm{C}_{17} \mathrm{H}_{19} \mathrm{~N}_{3} \mathrm{O}_{4}$ : C, 62.00; $\mathrm{H}, 5.81$; N, 12.76. Found: C, 62.19; H, 5.79; N, 12.75 .

Ethyl-6-amino-1,4-dihydro-3-methyl-4-(5-methylfuran-2-yl) pyrano[2,3-c]pyrazole-5-carboxylate (5f). M.P. $142^{\circ} \mathrm{C}$; IR (KBr): 3427, 3365, 3077, 2949, 1739, $1166 \mathrm{~cm}^{-1} ;{ }^{1} \mathrm{H}$ NMR $\left(\mathrm{DMSO}_{-} \mathrm{d}_{6}\right): 1.22\left(\mathrm{t}, 3 \mathrm{H}, \mathrm{CH}_{3}\right), 2.17\left(\mathrm{~s}, 3 \mathrm{H}, \mathrm{CH}_{3}\right), 2.75(\mathrm{~s}, 3 \mathrm{H}$, $\left.\mathrm{CH}_{3}\right), 4.17$ (q, 2H, $\left.\mathrm{CH}_{2}\right), 4.73(\mathrm{~s}, 1 \mathrm{H}, \mathrm{CH}), 6.02-6.28(\mathrm{~m}, 2 \mathrm{H}$, ArH), 6.65-6.95 (m, 4H, ArH), 7.03 (s, 2H, $\mathrm{NH}_{2}$ ), 12.02 (s, $1 \mathrm{H}, \mathrm{NH}) \mathrm{ppm} .{ }^{13} \mathrm{C} \mathrm{NMR}(400 \mathrm{MHz}, \mathrm{DMSO}): 10.32,13.64$, 14.2,z 38.72, 61.83, 78.72, 114.22-132.38, 140.04, 156.20, 159.40, $160.33,164.20$ ppm. Anal. calcd for $\mathrm{C}_{15} \mathrm{H}_{17} \mathrm{~N}_{3} \mathrm{O}_{4}$ : C, 59.40; $\mathrm{H}$, 5.65; N, 13.85. Found: C, 59.57; H, 5.63; N, 13.86 .

Ethyl-6-amino-1,4-dihydro-3-methyl-4-(thiophen-2-yl)pyrano [2,3-c]pyrazole-5-carboxylate (5g). M.P. $115^{\circ} \mathrm{C}$; IR (KBr): 
3416, 3352, 3099, 2940, 1722, $1279 \mathrm{~cm}^{-1} ;{ }^{1} \mathrm{H}$ NMR (DMSO$\left.\mathrm{d}_{6}\right): 1.24\left(\mathrm{t}, 3 \mathrm{H}, \mathrm{CH}_{3}\right), 2.72\left(\mathrm{~s}, 3 \mathrm{H}, \mathrm{CH}_{3}\right), 4.22\left(\mathrm{q}, 2 \mathrm{H}, \mathrm{CH}_{2}\right)$, $4.78(\mathrm{~s}, 1 \mathrm{H}, \mathrm{CH}), 6.60-6.91(\mathrm{~m}, 4 \mathrm{H}, \mathrm{ArH}), 6.69-6.98(\mathrm{~m}$, $3 \mathrm{H}, \mathrm{ArH}), 7.08$ (s, 2H, NH ), 12.04 (s, 1H, NH) ppm. ${ }^{13} \mathrm{C}$ NMR (400 MHz, DMSO): 10.38, 13.60, 38.80, 61.86, 78.72, 114.22-132.38, 123.6-139.4, 140.04, 156.22, 159.44, 160.36, 164.24 ppm. Anal. calcd for $\mathrm{C}_{14} \mathrm{H}_{15} \mathrm{~N}_{3} \mathrm{O}_{3} \mathrm{~S}$ : C, 55.07; H, 4.95; N,13.76. Found: C, 55.27; H, 4.93; N, 13.77 .

Ethyl-6-amino-1,4-dihydro-3-methyl-4-(pyridin-3-yl)pyrano [2,3-c]pyrazole-5-carboxylate (5h). M.P. $125^{\circ} \mathrm{C}$; IR (KBr): 3431, 3345, 3089, 2953, 1722, $1520 \mathrm{~cm}^{-1} ;{ }^{1} \mathrm{H}$ NMR (DMSO$\left.\mathrm{d}_{6}\right): 1.28\left(\mathrm{t}, 3 \mathrm{H}, \mathrm{CH}_{3}\right), 2.75\left(\mathrm{~s}, 3 \mathrm{H}, \mathrm{CH}_{3}\right), 4.17\left(\mathrm{q}, 2 \mathrm{H}, \mathrm{CH}_{2}\right)$, $4.73(\mathrm{~s}, 1 \mathrm{H}, \mathrm{CH}), 6.65-6.95(\mathrm{~m}, 4 \mathrm{H}, \mathrm{ArH}), 7.08(\mathrm{~s}, 2 \mathrm{H}$, $\mathrm{NH}_{2}$ ), 7.29-8.57 (m, 4H, ArH), (12.06 (s, 1H, NH) ppm. ${ }^{13} \mathrm{C}$ NMR (400 MHz, DMSO): 10.34, 13.62, 38.82, 61.80, 78.78, $114.20-132.20$, 123.34-152.56, 140.02, 156.20, 159.32, 160.32, 164.21 ppm. Anal. Calcd for $\mathrm{C}_{15} \mathrm{H}_{16} \mathrm{~N}_{4} \mathrm{O}_{3}$ : C, 59.99; $\mathrm{H}, 5.37$; $\mathrm{N}, 18.66$. Found: C, 59.81; H, 5.35; N, 18.65.

Ethyl-6-amino-1,4-dihydro-4-(2-hydroxyphenyl)-3-methylpyrano[2,3-c]pyrazole-5-carboxylate (5i). M.P. $143^{\circ} \mathrm{C}$; IR (KBr): 3410, 3389, 3335, 3072, 2931, $1734 \mathrm{~cm}^{-1} ;{ }^{1} \mathrm{H}$ NMR $\left(\mathrm{DMSO}_{-} \mathrm{d}_{6}\right): 1.30\left(\mathrm{t}, 3 \mathrm{H}, \mathrm{CH}_{3}\right), 2.79\left(\mathrm{~s}, 3 \mathrm{H}, \mathrm{CH}_{3}\right), 4.19(\mathrm{q}, 2 \mathrm{H}$, $\left.\mathrm{CH}_{2}\right), 4.74(\mathrm{~s}, 1 \mathrm{H}, \mathrm{CH}), 5.02(\mathrm{~s}, 1 \mathrm{H}, \mathrm{OH}), 6.46-6.54(\mathrm{~m}, 4 \mathrm{H}$, ArH), 7.06 (s, 2H, $\mathrm{NH}_{2}$ ), 12.08 (s, 1H, NH) ppm. ${ }^{13} \mathrm{C} \mathrm{NMR}$ (400 MHz, DMSO): 10.38, 13.64, 38.82, 55.68, 61.82, 78.78, $115.44-132.34,140.06,145.14,160.44,164.28$ ppm. Anal. calcd for $\mathrm{C}_{16} \mathrm{H}_{17} \mathrm{~N}_{3} \mathrm{O}_{4}$ : C, 60.94; $\mathrm{H}, 5.43 ; \mathrm{N}, 13.33$. Found: C, 60.73; $\mathrm{H}, 5.41 ; \mathrm{N}, 13.34$.

Ethyl-6-amino-1,4-dihydro-4-(3-hydroxy-4-methoxyphenyl)3-methylpyrano[2,3-c]pyrazole-5-carboxylate (5j). M.P. $145^{\circ} \mathrm{C}$; IR (KBr): 3431, 3369, 3342, 3082, 2943, 1729, 1142, $\mathrm{cm}^{-1} ;{ }^{1} \mathrm{H}$ NMR (DMSO-d $\left.)_{6}\right): 1.32\left(\mathrm{t}, 3 \mathrm{H}, \mathrm{CH}_{3}\right), 2.77\left(\mathrm{~s}, 3 \mathrm{H}, \mathrm{CH}_{3}\right), 3.71$ $\left(\mathrm{s}, 3 \mathrm{H}, \mathrm{OCH}_{3}\right) 4.17$ (q, 2H, $\left.\mathrm{CH}_{2}\right), 4.76(\mathrm{~s}, 1 \mathrm{H}, \mathrm{CH}), 5.22$ (s, $1 \mathrm{H}, \mathrm{OH}), 6.42-6.51$ (m, 3H, ArH), 7.07 (s, 2H, $\mathrm{NH}_{2}$ ), 12.09 (s, $1 \mathrm{H}, \mathrm{NH}), \mathrm{ppm} .{ }^{13} \mathrm{C}$ NMR (400 MHz, DMSO): 10.34, 13.68, 38.86, 55.66, 61.82, 78.78, 115.36-132.38, 140.08, 148.44, 158.12, $160.32,164.22$ ppm. Anal. calcd for $\mathrm{C}_{17} \mathrm{H}_{19} \mathrm{~N}_{3} \mathrm{O}_{5}: \mathrm{C}, 59.12 ; \mathrm{H}$, 5.55; N, 12.17. Found: C, 59.33; H, 5.57; N, 12.15 .

\section{Conclusion}

We have demonstrated a highly efficient green catalytic approach for the four-component one-pot synthesis of pyranopyrazole derivatives catalyzed effectively by $\mathrm{ZnO}$ nanoparticles. $\mathrm{ZnO}$ nanoparticles are well characterized by XRD technique. This method offers several advantages including avoidance of harmful organic solvents, high yield, short reaction time, simple work-up procedure, ease of separation, and recyclability of the catalyst.

\section{Acknowledgments}

The authors are thankful to the Dean and to the Head of the Department of Science and Humanities at FET, MITS, for providing necessary research facilities in the department.
Financial assistance from FET, MITS, is gratefully acknowledged. They are also thankful to SAIF Punjab University, Chandigarh, for the spectral and elemental analyses.

\section{References}

[1] R. V. A. Orru and M. Greef, "Recent advances in solution-phase multicomponent methodology for the synthesis of heterocyclic compounds," Synthesis, no. 10, pp. 1471-1499, 2003.

[2] M. Paravidino, R. S. Bon, R. Scheffelaar et al., "Diastereoselective multicomponent synthesis of dihydropyridones with an isocyanide functionality," Organic Letters, vol. 8, no. 23, pp. 5369-5372, 2006.

[3] N. Elders, R. F. Schmitz, F. J. J. Kanter, E. Ruijter, M. B. Groen, and R. V. A. Orru, "A resource-efficient and highly flexible procedure for a three-component synthesis of 2-imidazolines," Journal of Organic Chemistry, vol. 72, no. 16, pp. 6135-6142, 2007.

[4] B. Groenendaal, D. J. Vugts, R. F. Schmitz et al., "A multicomponent synthesis of triazinane diones," Journal of Organic Chemistry, vol. 73, no. 2, pp. 719-725, 2008.

[5] B. Groenendaal, E. Ruijter, and R. V. A. Orru, "1-Azadienes in cycloaddition and multicomponent reactions towards $\mathrm{N}$ heterocycles," Chemical Communications, no. 43, pp. 5474$5489,2008$.

[6] J. H. Clark, "Catalysis for green chemistry," Pure and Applied Chemistry, vol. 73, no. 1, pp. 103-111, 2001.

[7] V. J. Mohanraj and Y. Chen, "Nanoparticles: a review," Tropical Journal of Pharmaceutical Research, vol. 5, no. 1, pp. 561-573, 2006.

[8] D. Astruc, "Palladium nanoparticles as efficient green homogeneous and heterogeneous carbon-carbon coupling precatalysts: a unifying view," Inorganic Chemistry, vol. 46, no. 6, pp. 18841894, 2007.

[9] L.-S. Zhong, J.-S. Hu, Z.-M. Cui, L.-J. Wan, and W.-G. Song, "In-situ loading of noble metal nanoparticles on hydroxylgroup-rich titania precursor and their catalytic applications," Chemistry of Materials, vol. 19, no. 18, pp. 4557-4562, 2007.

[10] M. Moreno-Mañas and R. Pleixats, "Formation of carboncarbon bonds under catalysis by transition-metal nanoparticles," Accounts of Chemical Research, vol. 36, no. 8, pp. 638-643, 2003.

[11] D. Astruc, Nanoparticles and Catalysis, Wiley-VCH Verlag GMBH \& Co, 2008.

[12] L. Djakovitch, K. Koehler, and J. G. Vries, "The role of palladium nanoparticles as catalysts for carbon-carbon coupling reactions," Nanoparticles and Catalysis, vol. 65, pp. 303-348, 2008.

[13] J. Durand, E. Teuma, and M. Gómez, "An overview of palladium nanocatalysts: surface and molecular reactivity," European Journal of Inorganic Chemistry, no. 23, pp. 3577-3586, 2008.

[14] H. H. Kung, Transition Metal Oxides: Surface Chemistry and Catalysis, Elsevier Science, New York, NY, USA, 1989.

[15] D. Nohavica and P. Gladkov, "ZnO nanoparticles and their applications-new achievements," in Proceedings of the 2nd International Conference on Nanotechnology (NANOCON '10), Olomouc, Europe, 2010.

[16] F. M. Moghaddam, H. Saeidian, Z. Mirjafary, and A. Sadeghi, "Rapid and efficient one-pot synthesis of 1,4-dihydropyridine and polyhydroquinoline derivatives through the hantzsch four component condensation by zinc oxide," Journal of the Iranian Chemical Society, vol. 6, no. 2, pp. 317-324, 2009. 
[17] F. Tamaddon, M. A. Amrollahi, and L. Sharafat, "A green protocol for chemoselective O-acylation in the presence of zinc oxide as a heterogeneous, reusable and eco-friendly catalyst," Tetrahedron Letters, vol. 46, no. 45, pp. 7841-7844, 2005.

[18] B. V. Kumar, H. S. B. Naik, D. Girija, and B. V. Kumar, "ZnO nanoparticle as catalyst for efficient green one-pot synthesis of coumarins through Knoevenagel condensation," Journal of Chemical Sciences, vol. 123, no. 5, pp. 615-621, 2011.

[19] M. Hosseini-Sarvari, "Synthesis of quinolines using nano-flake $\mathrm{ZnO}$ as a new catalyst under solvent-free conditions," Journal of the Iranian Chemical Society, vol. 8, no. 1, pp. S119-S128, 2011.

[20] I. Yavari and S. Beheshti, " $\mathrm{ZnO}$ nanoparticles catalyzed efficient one-pot three-component synthesis of 2,3-disubstituted quinalolin-4(1H)-ones under solvent-free conditions," Journal of the Iranian Chemical Society, vol. 8, no. 4, pp. 1030-1035, 2011.

[21] H. Alinezhad, F. Salehian, and P. Biparva, "Synthesis of benzimidazole derivatives using heterogeneous $\mathrm{ZnO}$ nanoparticles," Synthetic Communications, vol. 42, no. 1, pp. 102-108, 2012.

[22] F. E. Goda, A. R. Maarouf, and E. R. EL-Bendary, "Synthesis and antimicrobial evaluation of new isoxazole and pyrazole derivatives," Saudi Pharmaceutical Journal, vol. 11, no. 3, pp. 111117, 2003.

[23] T. I. El-Emary, "Synthesis and biological activity of some new pyrazolo[3,4-b]pyrazines," Journal of the Chinese Chemical Society, vol. 53, no. 2, pp. 391-401, 2006.

[24] A. K. Mansour, M. M. Eid, and N. S. A. M. Khalil, "Synthesis and reactions of some new heterocyclic carbohydrazides and related compounds as potential anticancer agents," Molecules, vol. 8, no. 10, pp. 744-755, 2003.

[25] N. M. Abunada, H. M. Hassaneen, N. G. Kandile, and O. A. Miqdad, "Synthesis and antimicrobial activity of some new pyrazole, fused pyrazolo[3,4-d]-pyrimidine and pyrazolo[4,3e] $[1,2,4]$-triazolo[1,5-c]pyrimidine derivatives," Molecules, vol. 13, no. 7, pp. 1501-1517, 2008.

[26] R. R. Ranatunge, D. S. Garvey, D. R. Janero et al., "Synthesis and selective cyclooxygenase-2 (COX-2) inhibitory activity of a series of novel bicyclic pyrazoles," Bioorganic and Medicinal Chemistry, vol. 12, no. 6, pp. 1357-1366, 2004.

[27] A. A. Bekhit, H. M. A. Ashour, Y. S. Abdel Ghany, A. E.-D. A. Bekhit, and A. Baraka, "Synthesis and biological evaluation of some thiazolyl and thiadiazolyl derivatives of $1 \mathrm{H}$-pyrazole as anti-inflammatory antimicrobial agents," European Journal of Medicinal Chemistry, vol. 43, no. 3, pp. 456-463, 2008.

[28] R. Fioravanti, A. Bolasco, F. Manna et al., "Synthesis and biological evaluation of $\mathrm{N}$-substituted-3,5-diphenyl-2- pyrazoline derivatives as cyclooxygenase (COX-2) inhibitors," European Journal of Medicinal Chemistry, vol. 45, no. 12, pp. 6135-6138, 2010.

[29] S.-C. Kuo, L.-J. Huang, and H. Nakamura, "Synthesis and analgesic and antiinflammatory activities of 3,4-dimethylpyrano[2,3-c]pyrazol-6-one derivatives," Journal of Medicinal Chemistry, vol. 27, no. 4, pp. 539-544, 1984.

[30] S. J. Vaghasiya, D. K. Dodiya, A. R. Trivedi, and V. H. Shah, "Synthesis and biological screening of some novel pyrazolo $\left[3^{\prime}\right.$, $\left.4^{\prime}: 4,5\right]$ thieno[2,3-d]pyrimidin-8-ones via a Gewald reaction," Arkivoc, vol. 2008, no. 12, pp. 1-8, 2008.

[31] F. M. Abdelrazek, P. Metz, N. H. Metwally, and S. F. ElMahrouky, "Synthesis and molluscicidal activity of new cinnoline and pyrano[2,3-c]pyrazole derivatives," Archiv der Pharmazie, vol. 339, no. 8, pp. 456-460, 2006.

[32] G. Harshad, R. Kathrotiya, R. Patel, and M. P. Patel, "Microwave-assisted multi-component synthesis of indol-3-yl substituted pyrano[2, 3-c]pyrazoles and their antimicrobial activity," Journal of the Serbian Chemical Society, vol. 77, no. 8, pp. 983-991, 2012.

[33] M. B. Madhusudana Reddy and M. A. Pasha, "One-pot, multicomponent synthesis of $4 \mathrm{H}$-pyrano[2,3-c]pyrazoles in water at $25^{\circ}$ C," Indian Journal of Chemistry B, vol. 51, no. 3, pp. 537-541, 2012.

[34] P. V. Shinde, J. B. Gujar, B. B. Shingate, and M. S. Shingare, "Silica in water: a potentially valuable reaction medium for the synthesis of pyrano[2,3-c]pyrazoles," Bulletin of the Korean Chemical Society, vol. 33, no. 4, pp. 1345-1348, 2012.

[35] M. M. Heravi, A. Ghods, F. Derikvand, K. Bakhtiari, and F. F. Bamoharram, "H14[NaP5W30O110] catalyzed one-pot three-component synthesis of dihydropyrano[2,3-c]pyrazole and pyrano[2,3-d]pyrimidine derivatives," Journal of the Iranian Chemical Society, vol. 7, no. 3, pp. 615-620, 2010.

[36] H. Mecadon, M. R. Rohman, I. Kharbangar et al., "L-Proline as an efficicent catalyst for the multi-component synthesis of 6-amino-4-alkyl/aryl-3-methyl-2,4-dihydropyrano[2,3c]pyrazole-5-carbonitriles in water," Tetrahedron Letters, vol. 52, no. 25, pp. 3228-3231, 2011.

[37] S. N. Darandale, J. N. Sangshetti, and D. B. Shinde, "Ultrasound mediated sodium bisulfite catalyzed solvent-free synthesis of 6-amino-3-methyl-4-substitued-2,4-dihydropyrano[2, 3-c]pyrazole-5-carbonitrile," Journal of the Korean Chemical Society, vol. 56, no. 3, pp. 328-333, 2012.

[38] H. V. Chavan, S. B. Babar, R. U. Hoval, and B. P. Bandgar, "Rapid one-pot, four component synthesis of pyranopyrazoles using heteropolyacid under solvent-free condition," Bulletin of the Korean Chemical Society, vol. 32, no. 11, pp. 3963-3966, 2011.

[39] S. U. Tekale, S. S. Kauthale, K. M. Jadhav, and R. P. Pawar, "Nano$\mathrm{ZnO}$ catalyzed green and efficient one-pot four-component synthesis of pyranopyrazoles," Journal of Chemistry, vol. 2013, Article ID 840954, 8 pages, 2013.

[40] J. Safaei-Ghomi, A. Ziarati, and M. Tamimi, "A Novel method for the one-pot five-component synthesis of highly functionalized pyranopyrazoles catalyzed by $\mathrm{CuI}$ nanoparticles," Acta Chimica Slovenica, vol. 60, pp. 403-410, 2013.

[41] B. Myrboh, H. Mecadon, R. Rohman et al., "Synthetic developments in functionalized pyrano[2, 3-c]pyrazoles. A review," Organic Preparations and Procedures International, vol. 45, no. 4, pp. 253-303, 2013.

[42] G. Vasuki and K. Kumaravel, "Rapid four-component reactions in water: synthesis of pyranopyrazoles," Tetrahedron Letters, vol. 49, no. 39, pp. 5636-5638, 2008.

[43] M. Wu, Q. Feng, D. Wan, and J. Ma, "CTACl as catalyst for fourcomponent, one-pot synthesis of pyranopyrazole derivatives in aqueous medium," Synthetic Communications, vol. 43, no. 12, pp. 1721-1726, 2013.

[44] M. Bihani, P. P. Bora, and G. Bez, "Practical catalyst-free synthesis of 6-amino-4 alkyl/aryl-3-methyl-2,4-dihydropyrano[2,3c]pyrazole-carbonitrile in aqueous medium," Journal of Chemistry, Article ID 920719, 8 pages, 2013.

[45] H. Sachdeva and D. Dwivedi, "Lithium-acetate-mediated biginelli one-pot multicomponent synthesis under solvent-free conditions and cytotoxic activity against the human lung cancer cell line A549 and breast cancer cell line MCF7," The Scientific World Journal, vol. 2012, Article ID 109432, 2012.

[46] H. Sachdeva, D. Dwivedi, R. R. Bhattacharjee, S. Khaturia, and R. Saroj, "NiO nanoparticles: an efficient catalyst for the multicomponent one-pot synthesis of novel spiro and condensed 
indole derivatives," Journal of Chemistry, vol. 2013, Article ID 606259, 10 pages, 2013.

[47] A. Dandia, H. Sachdeva, and R. Singh, "Improved synthesis of 3-spiro indolines in dry media under microwave irradiation," Synthetic Communications, vol. 31, no. 12, pp. 1879-1892, 2001.

[48] C. Pacholski, A. Kornowski, and H. Weller, "Self-assembly of $\mathrm{ZnO}$ : from nanodots to nanorods," Angewandte Chemie, vol. 41, no. 7, pp. 1188-1191, 2002. 

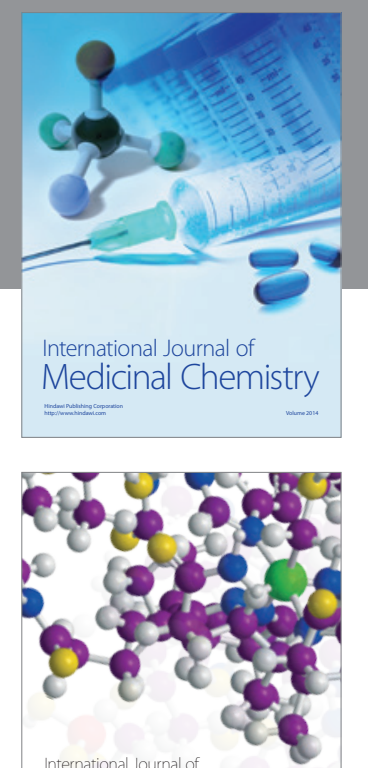

\section{Carbohydrate} Chemistry

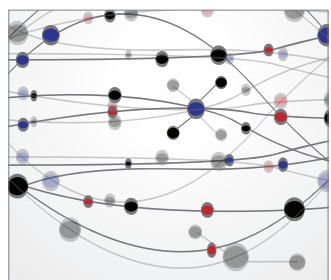

The Scientific World Journal
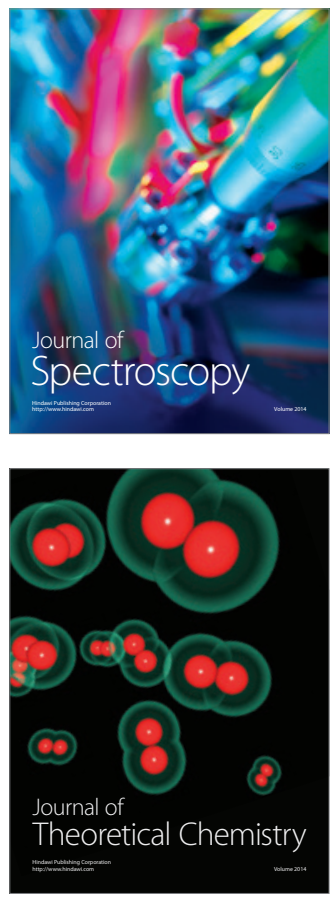
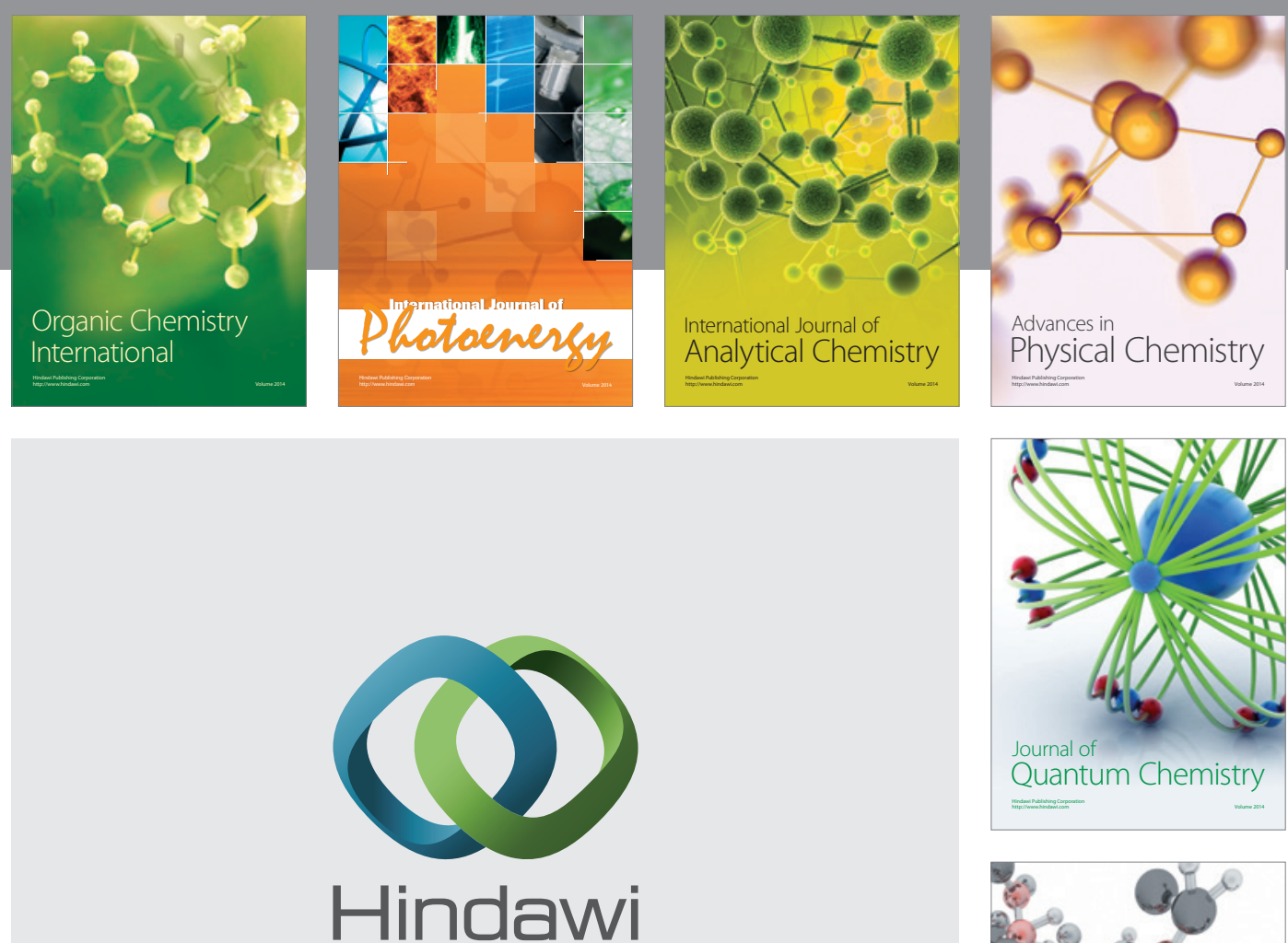

Submit your manuscripts at

http://www.hindawi.com

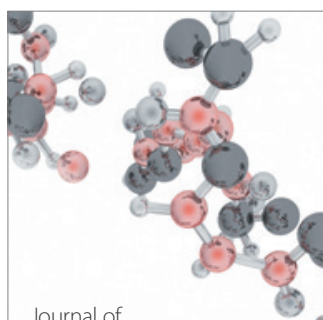

Analytical Methods

in Chemistry

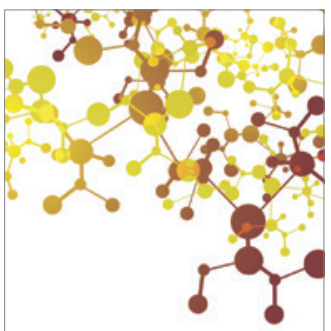

Journal of

Applied Chemistry

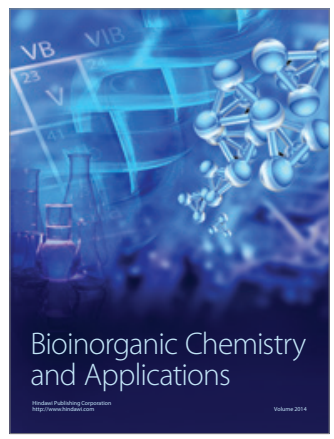

Inorganic Chemistry
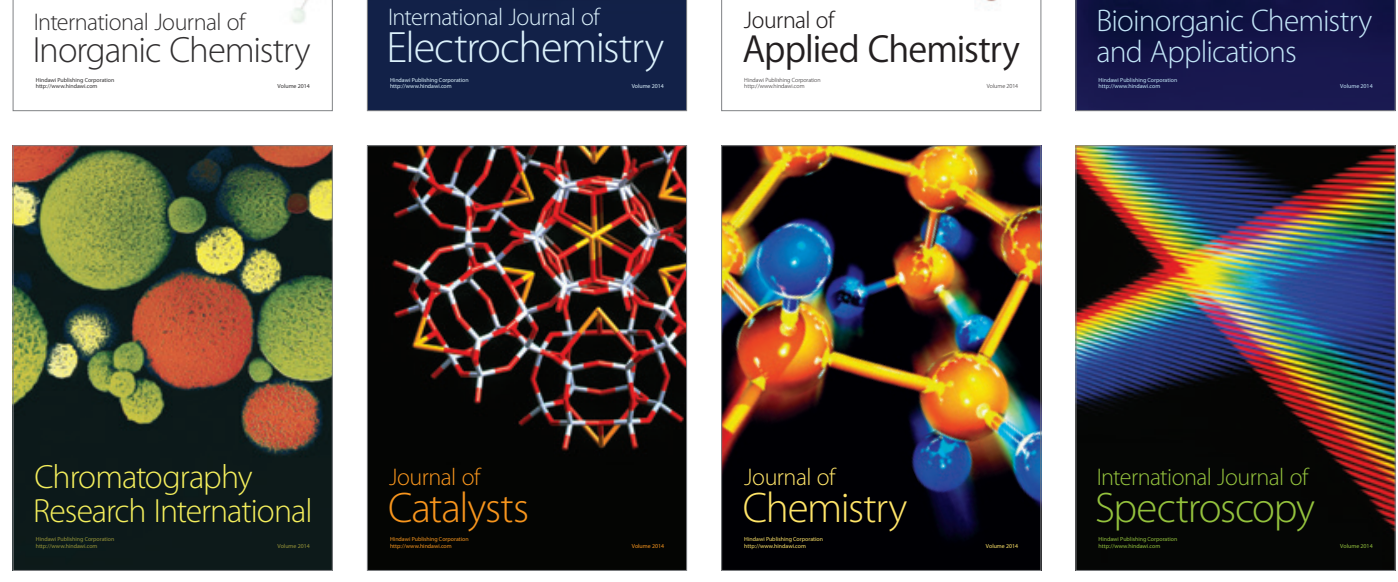